\title{
JUAN DE ARFE VILLAFAÑE Y SEBASTIANO SERLIO
}

\author{
POR \\ M. ${ }^{a}$ DEL CARMEN HEREDIA MORENO \\ Universidad de Alcalá
}

En este artículo se analiza el conocimiento y la utilización de los tratadistas italianos, particularmente de Sebastiano Serlio, por parte de Juan de Arfe. También se tratará de demostrar que la influencia de Serlio se percibe en buena parte de la producción del artífice, desde la custodia de Ávila hasta la de Valladolid, aunque se manifiesta de manera especial en los trabajos que Arfe realizó en Sevilla, sobre todo en los Libros I y IV de la Varia Commensuracion y en la custodia de la catedral.

Palabras clave: Platería española del Siglo xvi. Juan de Arfe. Sebastiano Serlio

Juan de Arfe's awareness and utilization of Italian art treatises, particularly that of Sebastiano Serlio, are analyzed in this study. The author demonstrates that Serlio's influence is perceptible in much of this artisan's production, from the Avila monstrance to that of Valladolid. It is especially manifest in Arfe's creations carried out in Seville, particularly in Books I and IV of his Varia Commensuracion and in the monstrance for the cathedral.

Key words: Spanish silverwork, 16th century. Juan de Arfe. Sebastiano Serlio

Desde la perspectiva del 2003, año en que se conmemora el IV Centenario de su muerte, Juan de Arfe y Villafañe (León 1535, Madrid 1603) sigue mereciendo, sin lugar a dudas, la consideración de figura cumbre en el panorama artístico español de la segunda mitad del siglo XVI. Hijo de Antonio de Arfe y nieto del maestro Enrique ${ }^{1}$, fue, a su vez, un consumado artífice platero, pero también un prototipo de humanista, a la manera del Renacimiento italiano ${ }^{2}$. Dotado de agudo espíritu crítico, amplia cultura, profundos conocimientos científicos y depurada técnica, desplegó una actividad polifacética, que le permitió descollar en variados ámbitos: arquitecto y escultor de oro y plata, experto en metales y en piedras preciosas, dibujante y grabador, teórico y práctico. De esta manera, como un intelectual en la plenitud de sus facultades y con la autoestima propia de su condición hidalga, y no como un artesano, nos lo muestra el retrato que

\footnotetext{
${ }^{1}$ Los primeros estudios de conjunto sobre la familia de los Arfe se deben a C. Justi: «Goldschmiedefamilie der Arphe», Miscellaneen aus drei jahrunderten Spanischen Kunstlebens, I, Berlín, 1908, p. 269-290, posteriormente traducida por Eduardo Ovejero: «Los Arfe», Estudios de Arte Español, Madrid, T. I, pp. 231-251, y F. J. Sánchez Cantón: Los Arfe, escultores de la plata y el oro, Madrid, 1920. Con independencia de su juicio de valor sobre el estilo de cada artífice, ambos historiadores resaltan la mayor dimensión de Juan de Arfe por su actividad teórica.

${ }^{2}$ Esta faceta de su personalidad ha sido analizada por A. Bonet Correa en su estudio introductorio a J. de Arfe: De Varia Commensuración..., Sevilla, 1985 (Edición facsímil, Madrid, 1974). Un amplio comentario sobre la Varia realiza también F. Íñiguez Almech en la edición facsímil de Albatros, Valencia, 1979, pp. 11-35.
} 
incorpora en la contraportada de la primera edición de la Varia Commensuracion a la edad de cincuenta años. En cuanto a su valía profesional, su categoría queda bien reflejada en su obra.

Arfe empezó su actividad como maestro independiente antes de 1564, fecha ésta en la que recibió el encargo de labrar la custodia de Ávila ${ }^{3}$. A partir de entonces, su prestigio creció de manera progresiva y fue solicitado por la clientela civil y eclesiástica más poderosa del momento. Trabajó fundamentalmente para catedrales, iglesias o monasterios en Sevilla, Valladolid, Burgos, Segovia, Burgo de Osma y Madrid, pero también, a partir de 1596, para los monarcas Felipe II y Felipe III y para el duque de Lerma ${ }^{4}$. Paralelamente desarrolló una importantísima labor teórica iniciada en el año 1572 con la publicación en Valladolid del Quilatador de oro, plata y piedras y continuada en Sevilla entre 1585 y 1587 con las dos primeras ediciones de la De Varia Commensuracion para la escultura y la architectura y la Descripcion de la traza y ornato de la custodia de Sevilla ${ }^{5}$. Además, en su juventud había sido mayordomo de la cofradía vallisoletana de Nuestra Señora del Val y San Eloy y en su madurez desempeñó el oficio de Ensayador Mayor de la Casa Vieja de la Moneda de Segovia, cargo para el que fue nombrado el 30 de diciembre de $1595{ }^{6}$. Fruto de su compleja trayectoria profesional y de su intensa labor, desarrollada a lo largo de casi cuarenta años, todavía se conservan cuatro custodias de asiento en las catedrales de Ávila, Sevilla y Valladolid y en el Museo de Santa Cruz de Toledo, además del viril de la de Burgos, la cruz del Seminario de Segovia, los relicarios del Monasterio de El Escorial y la escultura funeraria del arzobispo don Cristóbal de Rojas en la Colegiata de Lerma ${ }^{7}$. Esta última la fundió su yerno Lesmes Fernández del Moral después del fallecimiento del artífice acaecido el día 3 de abril de $1603^{8}$.

Pero su fama se mantuvo hasta bien entrado el siglo XIX gracias, sobre todo, a la difusión de su obra teórica De Varia Commensuracion, que fue reeditada ocho veces entre 1585 y 1806. A lo largo de estos dos largos siglos la Varia fue uno de los tratados de mayor éxito entre los artistas e intelectuales de la época ${ }^{9}$. Figura en las bibliotecas más significativos de nuestra

\footnotetext{
${ }^{3}$ Un análisis de la documentación e iconografía de esta obra en A. de la Cruz Vaquero y N. González González: La custodia del Corpus de Ávila, Ávila, 1993.

${ }^{4}$ Una completa síntesis y un estado de la cuestión sobre el platero en M. Herráez Ortega: «Los Arfe: Teoría y praxis», en La platería en la época de los Austrias Mayores en Castilla y León, Valladolid, 1999, pp. 98-107. J. M. Cruz Valdovinos: «Platería», Las artes decorativas en España (T. II), Madrid, 1999, p. 559, incorpora la cruz del seminario de Segovia, obra poco conocida del artífice.

${ }^{5}$ El estudio de A. Bonet Correa a la edición facsímil de la Varia..., pp. 7-24 incorpora una relación detallada de la obra teórica de Arfe con las diferentes ediciones de la misma hecha a partir del trabajo de F. Picatoste Rodríguez: Apuntes para una bibliografía científica española del siglo XVI, Madrid, 1891, pp. 16-19.

${ }^{6}$ A este cargo se refiere él mismo en el «Discurso a los lectores» de la segunda edición del Quilatador, impreso en Madrid en 1598. C. Pérez Pastor: Bibliografía madrileña. S. XVI, Madrid, 1891, n 561, pp. 288-290, dedica amplio espacio a esta obra.

${ }^{7}$ La primera biografía de Juan de Arfe se debe a A. Ceán Bermúdez: Diccionario de los más ilustres profesores de las Bellas Artes en España, Madrid, 1800, T. I, pp. 60-67. Desde finales del siglo xix publicaron abundante documentación C. Pérez Pastor: «Problema histórico-artístico», Revista de Archivos, bibliotecas y Museos, n 5, 1901, pp. 281-289 y «Documentos sobre Juan de Arfe Villafañe», Bibliografía madrileña, T. III, Madrid, 1907. J. Martí I Monsó: Estudidos histórico artísticos relativos principalmente a Valladolid, Valladolid, 1907-8. E. García Chico: Documentos para el estudio del arte en Castilla, Valladolid, 1963, pp. 38-57. Entre los estudios modernos citamos, aparte de los ya mencionados, a J. M. Cruz Valdovinos: «La custodia del Museo de Santa Cruz de Toledo», Archivo Español de Arte, 1977, pp. 9-29 y «El platero Juan de Arfe y Villafañe», Iberjoya, 1983, pp. 3-22. Ma J. Sanz Serrano: Juan de Arfe Villafañe y la custodia de Sevilla, Sevilla, 1978. J. C. Brasas Egido: La platería vallisoletana y su difusión, Valladolid, 1980, pp. 139-141. F. Martín: «La fuente y el aguamanil de Juan de Arfe», Archivo Español de Arte, n 212, 1980, pp. 497-499 y «Relicarios y piezas de altar en la basílica del Monasterio de El Escorial», Reales Sitios, 1984, pp. 29-36. M. T. Maldonado Nieto: «La cruz metropolitana de la catedral de Burgos y un nuevo aspecto en la obra de Juan de Arfe», Archivo Español de Arte, n 235, 1986, pp. 304319. A. Barrón García: «Juan de Arfe en Burgos», Burgense, n 35/1 1994, pp. 249-278.

${ }^{8}$ L. Cervera Vera: La iglesia parroquial de San Pedro en Lerma, Burgos, 1981, p. 52.

${ }^{9}$ Sobre la fortuna de la Varia, consúltense los epígrafes «Aprecio y elogio de la Varia» y «Utilización y vigencia de la Varia» que incorpora A. Bonet Correa en las citadas ediciones facsímiles, recogidas también en Figuras, modelos e imágenes en los tratadistas españoles, Madrid, 1993, pp. 66-70 y 87-88.
}

AEA, LXXVI, 2003, 304, pp. 371 a 388 
Edad de Oro, desde la de Juan Gómez de Mora hasta la de Velázquez, plateros inclusive, y lo utilizan, a su vez, los tratadistas del Barroco como punto de partida para su teoría ${ }^{10}$. Francisco Pacheco cita a Arfe en El Arte de la Pintura al mismo nivel que a Durero ${ }^{11}$. Fray Lorenzo de San Nicolás resume el contenido de la Varia en la segunda parte de su Arte y uso de Architectura ${ }^{12}$. Antonio Palomino copia algunas de sus láminas en su Museo Pictórico y Escala Ópti$\mathrm{ca}^{13}$ y el propio Ventura Rodríguez, arquitecto y director de arquitectura de la Academia de Bellas Artes de San Fernando, lo utilizaba como texto escolar y hacía copiar a sus alumnos dibujos y párrafos del tratado de Arfe ${ }^{14}$. Hoy día, tras el paréntesis negativo que supuso la crítica adversa de Menéndez Pelayo y la parcial incomprensión de Sánchez Cantón ${ }^{15}$, la figura de Juan de Arfe ha vuelto a recuperar su auténtico valor como maestro de primera fila a partir, sobre todo, de los estudios de Bonet Correa, Sanz Serrano y Cruz Valdovinos ${ }^{16}$.

La mayoría de los estudiosos de Juan de Arfe han concentrado la investigación en los documentos y en las piezas conservadas del artífice, tratando de profundizar en su biografía, relaciones familiares y profesionales, trayectoria artística y análisis estilístico e iconográfico, campos todos ellos en los que se han logrado notables avances. Su obra teórica ha sido también objeto de especial atención por parte de Bonet Correa en sus excelentes comentarios a las dos primeras ediciones de la Varia ${ }^{17}$. Con frases certeras, el profesor Bonet apuntó la influencia del tratadista italiano Sebastiano Serlio en muchos de los dibujos del libro de Arfe, abriendo una vía de investigación imprescindible para lograr la cabal comprensión del artífice, que, sin embargo, todavía no ha sido explorada en profundidad. Éste es el objetivo principal de estas páginas.

Tras la la revisión detenida de la trayectoria y de la obra de Juan de Arfe hemos podido comprobar que su conocimiento de los tratadistas italianos, sobre todo de Sebastiano Serlio, y la utilización de su vocabulario formal se inició al comienzo de su carrera artística, cuando estaba labrando la custodia de Ávila. No obstante, fue durante sus años pasados en Sevilla entre 1580 y 1587 , trabajando para el cabildo de la catedral y mediante sus contactos con los intelectuales y artistas sevillanos del entorno de la Academia de Pacheco, cuando asimiló en profundidad este lenguaje y lo incorporó de forma más consciente en su obra teórica y práctica, como iremos analizando.

Cuando Juan de Arfe comenzó la custodia de Ávila era ya un maestro independiente. Había aprendido el oficio en el taller de su padre y posiblemente habría colaborado con su progenitor en la custodia de Medina de Rioseco, concluida en 1554. Al año siguiente completó su

\footnotetext{
${ }^{10}$ Sobre los libros de Juan Gómez de Mora puede consultarse V. Tovar: Arquitectura madrileña del siglo xvil, Madrid, 1983, p. 181 . La relación de libros del inventario de bienes de Velázquez la dio a conocer F. Rodríguez Marín: Francisco Pacheco, maestro de Velázquez, Madrid, 1923. El inventario fue transcrito por F.J. Sánchez Cantón: «Cómo vivía Velázquez», Archivo Español de Arte, 1942, pp. 69 y ss.. Se vuelve a reproducir completo en el documento n 209 de Varia Velazqueña, T.II, Madrid, 1960, pp. 391-400; en p. 397: «414: Juan de Arfe Varia Commesuracion de a folio». J. L. Barrio Moya: «La librería del platero Juan de Orea», Boletín de Arte, n 11, 1990, pp. 97-103.

${ }^{11} \mathrm{~F}$. Pacheco: El arte de la pintura, edición, introducción y notas de B. Bassegoda i Hugas, Madrid, 1990, pp. 33, 36, $65,67,349-50,356-357,361-63,379-80,385$ y 391.

${ }^{12}$ Hemos consultado la edición facsímil de Madrid, 1974, con estudio introductorio de J. J. Martín González.

13 A. Bonet Correa: «Láminas de «El Museo Pictórico y Escala Óptica» de Palomino», Archivo Español de Arte, T. XLVI, n 182, 1973, pp. 131-144.

${ }^{14}$ En la nota 48 de su citado estudio sobre la Varia, A Bonet Correa recoge un manuscrito De Frc ${ }^{\circ}$ Santos de Thorres $y$ Amattria copiado en la Academia de San Fernando: sacado por Don Bentura Rodriguez. Año 1786, propiedad de C. Sambricio, que incluye 18 páginas y 5 dibujos de Arfe

${ }^{15}$ Es bien conocido el juicio negativo de M. Menéndez Y Pelayo: «Juan de Arfe», Historia de la ideas estéticas en España, Madrid, 1947, pp. 381-84. Sobre la valoración de Sánchez Cantón, véase el capítulo III de su mencionada obra Los Arfe..., pp. 47-74.

${ }^{16}$ Véase la bibliografía citada en las notas 2,4 y 7.

17 Tomando como punto de partida los escritos de Bonet Correa se han realizado algunos comentarios a la obra teórica de Arfe por parte de $\mathrm{M}^{\mathrm{a}} \mathrm{J}$. Sanz Serrano: «Aspectos teóricos de la obra literaria de Juan de Arfe», Actas del VIII Congreso Nacional de Historia del Arte, I, Mérida, 1992, pp. 317-322 y D. García López: «De «platero» a «escultor y arquitecto de plata y oro»: Juan de Arfe y la teoría artística, Estudios de platería. San Eloy 2002, Murcia, 2002, pp. $127-142$.
} 
formación en Salamanca asistiendo a las clases de anatomía del doctor Medina. A su vuelta a Valladolid, es probable que reanudase la colaboración con Antonio de Arfe y que quizás le ayudase hacia 1564 en el «sillón de plata y guarnición de aderezo» encargado por Diego Mejías, vecino de Ávila ${ }^{18}$. Creemos que pudo ser éste o algún otro cliente paterno, como el obispo de Ávila don Álvaro de Mendoza, el que conectase a Juan con el cabildo de la catedral facilitándole así su primer gran encargo.

De cualquier manera, la custodia abulense, de tipo turriforme y con cinco cuerpos más linterna, es una obra ambiciosa que evidencia el entusiasmo juvenil del platero, preocupado por mostrarnos su virtuosismo técnico y sus conocimientos arquitectónicos y escultóricos ${ }^{19}$. De ahí la complejidad de su traza, con gran número de cuerpos, variedad de arcos y multiplicidad de soportes, que dan como resultado un conjunto monumental pero falto de unidad y de aspecto algo confuso por la mezcla de formas muy heterogéneas ${ }^{20}$. Efectivamente, a sus cuerpos de planta hexagonal y circular se añaden torres angulares de base cuadrada. Como soportes se utilizan pilares, columnas de órdenes jónico, corintio y compuesto, hermes estípites y balaustres. Por último, tiene arcos rebajados, de medio punto y en ángulo, además de dinteles (Fig. 1). Parte de este vocabulario procede del lenguaje formal de su padre, Antonio de Arfe, que, en opinión de su hijo, fue uno de los primeros en utilizar de manera coherente las formas renacentistas ${ }^{21}$. Antonio había aprendido con su padre y, sobre todo, de sus contactos con su primo Enrique Belcove, colaborador de Francisco Becerril en la custodia de Villaescusa de Haro (Cuenca) en el año $1529^{22}$. De la custodia de Medina de Rioseco, labrada por Antonio en 1554 con la posible participación de Juan, procede, en efecto, el mantenimiento de las torres angulares en la pieza de Ávila, su mezcla de plantas y de soportes e, incluso, sus formas más novedosas, como los hermes del cuarto cuerpo que reproducen las del segundo cuerpo de la custodia de Medina. La fuente directa de inspiración para esta última debieron ser, lógicamente, los hermes que, quizás por primera vez en la arquitectura castellana, habían incorporado Juan y Jerónimo Corral en el flanco norte de la capilla funeraria de los Benavente, comenzada en 1544 en esta misma iglesia de Santa María de Medina de Rioseco ${ }^{23}$. El modelo para los arquitectos fue, a su vez, la portada de los Libros III y IV de Arquitectura de Sebastiano Serlio publicado en Bolonia en 1537. De forma paralela, Francisco de Villalpando introducía estos mismos soportes en la reja de la catedral de Toledo ${ }^{24}$. Y da la casualidad que fue este último maestro,

\footnotetext{
${ }^{18}$ La noticia procede de E. García Chico: Documentos..., p. 32. Sobre la obra civil de Antonio de Arfe y sus encargos para la nobleza, véanse además C. Brasas Egido: La platería vallisoletana y su difusión, Valladolid, 1980, pp. 137-139. M. A. Fuentes: «Dos dibujos de Antonio de Arfe», Boletín del Seminario de Arte y Arqueología de Valladolid, ${ }^{\circ}$ 53, 1987, pp. 347-349. J.M. Cruz Valdovinos: «Antonio de Arfe y la custodia de la catedral de Santiago», en Galicia no tempo, Santiago de Compostela, 1991, pp. 247-259. B. Santamarina: «Obra documentada de Antonio de Arfe para el VI conde de Benavente. Estudio de tipos de platería civil en el siglo xvI», Anuario del Departamento de Historia y Teoría del Arte (U.A.M.), Vol. VI (1994) 197-204.

${ }^{19}$ Aparte del reciente estudio de Cruz Vaquero, citado en la nota 3, también trataron sobre esta custodia J. Agapito y Revilla: «La custodia de la catedral de Ávila», Boletín de la Sociedad Castellana de Excursiones, 1909-10, pp. 142-146. M. Trens: Las custodias españolas, pp. 42-44 y C. Hernmarck: Las custodias procesionales en España, Madrid, 1987, p. 152.

${ }^{20}$ Sánchez Cantón: Los Arfe..., p. 152, la califica de «mezcla poco aforturnada» y «ensayo falto de madurez». Para S. Alcolea: Artes decorativas..., p. 196, resulta un conjunto «forzado en su altura, con escasa unidad y armonía en sus proporciones y con diversidad de soluciones en los soportes, ya sean columnas o estípites». Para Ma J. Sanz Serrano: Juan de Arfe..., p. 122, es obra inmadura, aunque de gran calidad en los relieves.

${ }^{21}$ J. de Arfe Villafañe: De Varia Commensuración..., L. IV, Tít. I, f. 3: «Aunque la architectura (romana) estava en los edificios y templos casi introduzida en España, jamas en las obras de plata se avia seguido enteramente hasta que Antonio de Arphe mi padre la començo a usar en la custodia de Santiago de Galizia y en la de Medina de Rioseco y en las andas de Leon».

${ }^{22}$ A. López Yarto Elizalde: Francisco Becerril, Madrid, 1991, p. 12.

${ }^{23}$ E. García Chico: «La Capilla de los Benavente en Santa María de Rioseco», Boletín del Seminario de Estudios de Arte y Arqueología, Valladolid, 1934, p. 321. T. Gómez Espinosa y G. Sardiñas González: «La obra de los Corral», La obra en yeso policromado de los Corral de Villalpando, Madrid, 1994, p. 25.

${ }^{24}$ F. Marías: La arquitectura del Renacimiento en Toledo (1541-1631), Toledo, 1983, T. I, p.318-320. V. Nieto, A. Morales y F. Checa: Arquitectura del Renacimiento en España, 1488-1599, Madrid, 1989, pp. 202-203.
}

$A E A$, LXXVI, 2003, 304, pp. 371 a 388 

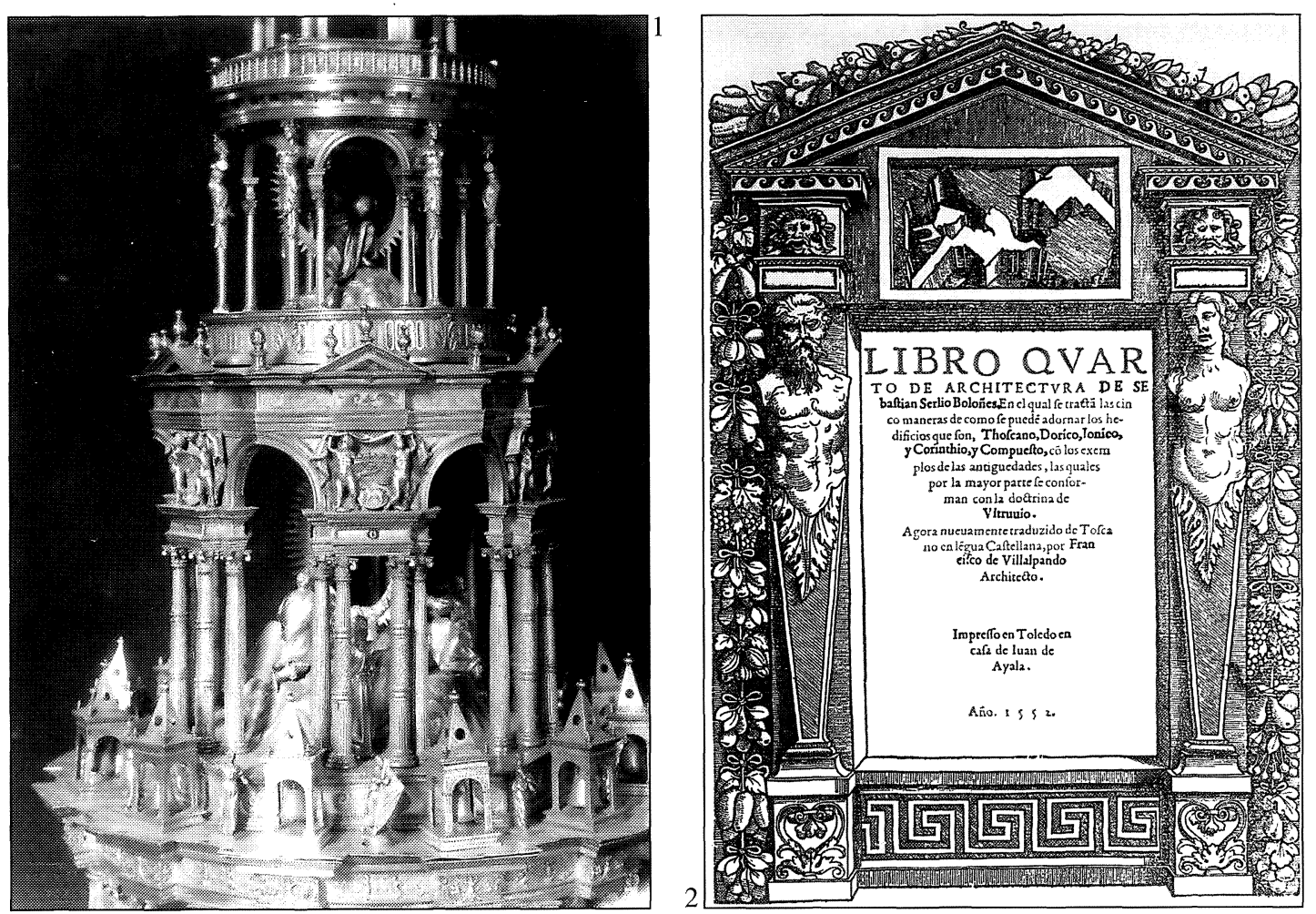

Fig. 1. Arfe. Custodia. Catedral de Ávila. Cuerpos superiores (Foto CSIC).

Fig. 2. Serlio. Libro Quarto de Architectura. Portada.

hermano de los anteriores, el que tradujo al castellano en el año 1552 el texto del boloñés, ampliamente difundido y utilizado por toda Castilla a partir de esta fecha (Fig. 2). En este ambiente, la procedencia serliana de los hermes de la custodia de Ávila parece probada y tanto el interés inicial despertado por el conocimiento directo de la capilla de los Benavente, como el ejemplo paterno y, sobre todo, las estampas de la reciente edición de Serlio, debieron influir decisivamente en la adopción de estos motivos, que, por otra parte, Juan de Arfe utiliza como soporte estructural y no como simple forma decorativa. El inventario «post mortem» del artífice muestra que poseía los Libros III y $I V$ de Serlio, que, pensamos, pudo adquirir en Valladolid o en Toledo recién publicada la edición de Villalpando ${ }^{25}$.

Además, este cuarto cuerpo de la custodia de Ávila tiene planta circular y se articula por parejas de columnas corintias que sujetan arcos de medio punto, de manera que los hermes exentos componen un peristilo, el cual se corona por una barandilla con balaustrada que acentúa la centralidad del templete al subrayar la disposición de los elementos en bandas concéntricas. El resultado no deja de ser novedoso en el panorama de la platería contemporánea, pero supone, en definitiva, otra aproximación al lenguaje de Serlio por parte de Juan de Arfe. En este caso, el punto de partida parece el dibujo del alzado del templete de San Pietro in Montorio reproducido en el Libro III, folio XXIIII (Fig. 17). Incluso el quinto cuerpo de la custodia de Ávila, con cubierta de media naranja apeada en pilares, evoca el remate de Bramante según el citado dibujo de Serlio. Otros elementos característicos claramente tomados del boloñés son las serlianas que articulan el tercer cuerpo de esta misma custodia, si bien aquí se adaptan al

\footnotetext{
${ }^{25}$ Recogido por E. García Chico: Documentos..., p. 55 y J.L. Barrio Moya: «El platero Juan de Arfe Villafañe y el inventario de sus bienes», Anales del Instituto de Estudios Madrileños, T. XIX, 1966, p. 8, como «Tercero y quarto libro de sevastian serlio en beinte y quatro rreales».
} 
orden corintio de los soportes frente al dórico o jónico que se reproducen en los folios XXXV y XXXVI de su Libro IV. Es decir, pese a que el conjunto de la custodia de Ávila resulte algo confuso por la excesiva acumulación de elementos heterogéneos, es evidente que Juan de Arfe se interesa por las novedades y trata de asimilar el lenguaje del tratadista italiano iniciando aquí su particular camino hacia el Manierismo y el Clasicismo.

Parecido carácter innovador presentan algunas figuras y relieves de la custodia, próximos a Gaspar Becerra al que pudo conocer personalmente en Valladolid, ya que el escultor se estableció en la ciudad en 1557 tras su vuelta de Roma ${ }^{26}$. Incluso la estructura de los respaldos de los asientos de los profetas rematan en frontones rectos apeados en ménsulas, de manera semejante a las cajas del retablo de Astorga que Becerra comenzó en esta misma fecha.

El traslado de Juan de Arfe a Sevilla a finales de 1579 para labrar la custodia de la catedral y su consiguiente estancia en la capital andaluza durante siete largos años fue decisivo para la asimilación de la obra de Serlio. Según Schlosser, ya su primer libro publicado (el cuarto) había difundido su fama por todo el mundo ${ }^{27} \mathrm{y}$, como Carlos Sambricio ha subrayado, su tratado tuvo preponderancia progresiva por Europa a lo largo de la segunda mitad del siglo xvI, pese a que en buena medida sólo era una simple transcripción de la arquitectura de Bramante y Sangallo o de los dibujos de su maestro, Baldassare Peruzzi, que heredó a su muerte, porque, en cualquier caso, la obra teórica del boloñes fue una referencia obligada gracias a la cual el Clasicismo se convirtió en un lenguaje común ${ }^{28}$. También en Sevilla la obra de Serlio fue determinante para muchos artistas de prestigio interesados por la tratadística italiana. Un ejemplo expresivo es el de Hernán Ruiz «el Joven», uno de los grandes creadores de la arquitectura del Renacimiento en España, el más importante de Andalucía Occidental, nombrado maestro mayor de la catedral de Sevilla en 1557, del Hospital de las Cinco Llagas en el 1558, del ayuntamiento hispalense en el 1560 y de su Arzobispado en el $1562{ }^{29}$.

Cuando Arfe llegó a la ciudad, Hernán Ruiz ya había fallecido, pero pudo contemplar sus obras en la propia catedral y asistir al proceso constructivo de las que todavía se encontraban en curso de realización por mano de sus seguidores y bajo la supervisión de canónigos expertos, como Luciano de Negrón y Francisco Pacheco. El primero, reputado astrólogo y humanista que mereció un puesto entre los «varones ilustres» del Libro de los Retratos del pintor Francisco Pacheco, fue uno de los capitulares encargado del seguimiento de la Sala Capitular y formó parte de la comisión que adjudicó el concurso de la custodia a Juan de Arfe ${ }^{30}$. El segundo, tío del pintor homónimo, fue el mentor de dicha custodia. Todas las obras trazadas por Hernán Ruiz para la catedral ofrecían acusadas influencias de Serlio, tanto las de planta central o centralizada - el remate de la Giralda, la Sala Capitular o el desaparecido tabernáculo del Sagrario-, como las estructuras y portadas del Antecabildo, el Patio del Cabildo y la Casa de Cuentas, algunas de estas últimas inspiradas en el Libro VI o Libro Extraordinario, editado en Lyon en el año 1551 y no traducido al castellano ${ }^{31}$. Además, varias de estas últimas trazas las reproduce también Hernán Ruiz «el Joven» en su Manuscrito de Arquitectura realizado en torno a 1560, igual que algunos dibujos de geometría y de vasos, tomados estos últimos del

\footnotetext{
${ }^{26}$ J. Camón Aznar: Escultura y rejería española del siglo xvı, Madrid, 1989, p.310.

${ }^{27}$ J. Schlosser: La literatura artística, Madrid, 1976, pp. 350-351.

${ }^{28}$ Véase la edición del Colegio Oficial de Aparejadores y Arquitectos Técnicos, Todas las obras de arquitectura y perspectiva de Sebastiano Serlio de Bolonia, con introducción de C. Sambricio y estudio lingúistico de F. Díaz Padilla, Oviedo, 1986, p.17. Véase también J.R. Paniagua Soto: Sebastián Serlio y su influencia en la arquitectura española. La traducción de Francisco de Villalpando, Madrid, 1991, 3 vols.

${ }^{29}$ A. Morales: «Tradición y modernidad», en Arquitectura del Renacimiento..., 163-174 y Hernán Ruiz «el Joven», Madrid, 1996.

${ }^{30}$ J. Ma Gentil Baldrich: «El libro de perspectiva», en el Libro de Arquitectura. Hernán Ruiz, Sevilla, Edición facsímil de la Fundación Sevillana de Electricidad, 1998, V. II, pp. 231.

${ }^{31}$ Sobre su importante labor como arquitecto de la catedral de Sevilla, véase A. Morales: Hernán Ruiz..., pp. $23-57$.
}

AEA, LXXVI, 2003, 304, pp. 371 a 388 
Libro I de Serlio, publicado en el año 1545 y tampoco traducido ${ }^{32}$. Estas circunstancias evidencian que el arquitecto andaluz poseyó o consultó con frecuencia la obra completa del tratadista italiano. Existen numerosas incógnitas sobre la trayectoria posterior de su Manuscrito, pero se conoce que los posibles herederos poseían importantes bibliotecas y pudieron relacionarse con Arfe en Sevilla. Su hermano, Francisco Sánchez, continuó como aparejador del Hospital de las Cinco Llagas hasta 1584 y recibió como legado un libro de León Baptista Alberti y la Jumetría e alquitatura de Alberto Durero. Por otra parte, el propio Hernán Ruiz «el Joven» declara en su testamento que «Yten mando todos mis libros a Hernán Ruiz, mi hijo, maestro mayor de las obras de la Santa Yglesia de Córdoua, y encargo al dicho mi hijo que quando Francisco Sánchez, mi hermano, a quien tengo mandados dos libros conforme a la cláusula antes desta tuviere necesidad de comunicar con el dicho mi hijo algunos libros se los comunique». Por último, su colaborador Juan de Minjares trabajó para la catedral hispalense desde 1583 en adelante y tenía en su librería los cinco primeros libros de arquitectura de Serlio, además de los de Alberti, Vitrubio y Daniel Bárbaro ${ }^{33}$.

En cuanto a los maestros plateros que trabajaban para la catedral de Sevilla, Arfe coincidió y contactó con Hernando de Ballesteros el Mozo, con Francisco Merino, su mayor oponente en el concurso para la custodia, y con Francisco de Alfaro. Este ultimo artífice, maestro de reconocido prestigio y bien conocido en el entorno de la catedral, concluía en 1581 la custodia de la parroquia de San Juan de Marchena que muestra su profundo conocimiento del léxico de Serlio ${ }^{34}$.

La relación de Arfe con todos estos artistas y canónigos cultos de la catedral y su conexión con los círculos literarios de la Academia, donde se introdujo gracias a los capitulares Negrón y Pacheco, así como los consiguientes contactos con los intelectuales y humanistas más destacados del momento, como Francisco de Medina o Fernando de Herrera, le permitirían profundizar en el estudio de la tratadística italiana mediante la consulta de otras bibliotecas bien surtidas, algunas de las cuales, como la del propio Luciano de Negrón, compuesta por cerca de cinco mil volúmenes, seguro que incluirían la obra completa de Serlio entre los tratados más novedosos ${ }^{35}$. En la Academia encontró también Arfe a su medio paisano, Rodrigo Zamorano, «Astrólogo y Mathemático y Cathedrático de Cosmographía por su Magestad», que residía en la ciudad desde 1574 y que había dedicado al canónigo Negrón su traducción de los seis primeros libros de geometría de Euclides editados en Sevilla en el año $1576{ }^{36}$. Este texto había sido un punto de referencia obligado para los teóricos del Mundo Clásico y del Renacimiento, desde Vitrubio hasta Alberti, Durero y el propio Serlio, por lo que resultaba imprescindible para comprender la tratadística de arquitectura del quinientos. Además, Zamorano fue también el primer traductor de Alberti al español y su traducción de De re aedificatoria se publicó en

\footnotetext{
${ }^{32}$ Además de A. Morales: Hernán Ruiz..., véanse P. Navascués Palacio: El Libro de Arquitectura de Hernán Ruiz, el Joven, Madrid, 1974, pp. 9-12 y A. Jiménez Martín: «Contexto de la presente edición», en Libro de Arquitectura..., V. II, pp. $15-22$.

${ }^{33}$ Un estado de la cuestión sobre la trayectoria del manuscrito en A. Jiménez Martín: «Contexto...» y C. Álvarez Márquez: «La traducción de Vitrubio y otras cuestiones», en Libro de Arquitectura ..., V. II, pp. 15-22 y 85. Juan de Minjares poseía también la Varia y el Quilatador del propio Arfe.

${ }^{34}$ J. L. Ravé Prieto: Arte religioso en Marchena. Siglos XV al XIX, Marchena, 1986, pp. 30-31. Sobre otras custodias de Alfaro realizadas por estas fechas, Ma J. Mejías: Orfebrería religiosa en Carmona, Carmona, 2001, pp. 225-229. G. García León: Écija y el culto a la Eucaristía, Écija, 2002, pp. 46.53.

${ }^{35}$ Sobre las bibliotecas de la época pueden consultarse P. Ruiz: Libros y lecturas de un poeta humanista. Fernando de Herrera (1534-1597), Córdoba, 1997. A. Rodríguez Moñino: La biblioteca de Arias Montano y documentos para su reconstrucción, 1548-1598, Badajoz, 1919, V. LLeó Cañal: La Casa de Pilatos, Madrid, 1998, pp. 67-68. L. Méndez Rodríguez, «Lecturas y miradas de un humanista. La colección del canónigo Luciano de Negrón», Archivo Hispalense, ${ }^{\circ} 252$ (2000) 115-138.

36 Los seis libros primeros de la geometría de Euclides. Traduzidos en lengua Española por Rodrigo çamorano...dirigidos al illustre señor Luciano de Negrón...1576. Edición facsímil, Salamanca, 1999, con estudio introductorio de J. Ma Sanz Hermida.
} 
Toledo en 1582, por el impresor Alonso Gómez, bajo la autoría de Francisco Lozano ${ }^{37}$. Por lo tanto, como recientemente se ha puesto de manifiesto, habría que considerar la amistad que pudiera existir entre los dos maestros vallisoletanos, Zamorano y Arfe, y la posibilidad de que sus buenas relaciones se hicieran extensibles al ámbito profesional, hasta el punto de existir una colaboración estrecha, ya que ambos tenían intereses comunes ${ }^{38}$. El primer Libro de la Varia, dedicado precisamente a la geometría, parte del conocimiento de Serlio y del propio Euclides, aparte de Durero, Hernán Ruiz y otros. Es decir, con independencia de que Arfe tuviera ya en su poder el «bocabulario de las dos lenguas toscana e ytaliana», que se recoge en su inventario «post mortem» y que le permitiría estudiar los textos en su idioma original, es evidente que su relación con Zamorano facilitaría su comprensión de la geometría euclidiana y este conocimiento haría posible una interpretación personal de algunos dibujos del I Libro de Geometría de Serlio en lugar de una simple copia.

A tenor de todo lo expuesto, creemos que fue en Sevilla donde Arfe encontró el clima más favorable para profundizar en el estudio de Serlio, ya que su actividad profesional durante estos años propició los contactos con los arquitectos y plateros de la catedral así como su aproximación a los humanistas y científicos de la Academia. Estas circunstancias le permitieron manejar personalmente la obra completa del tratadista italiano a través de los ejemplares de alguna biblioteca sevillana y analizar la obra de Euclides con un experto en geometría. Paralelamente Arfe iría completando su propia biblioteca, añadiendo a los volúmenes adquiridos con anterioridad, como la ya mencionada traducción de Villalpando o la Anatomía de Valverde, otros títulos específicos sobre arquitectura y geometría. Entre ellos se recogen y tasan en su «inventario post mortem» las Regole dei cinque ordine de Arquitettura de Vignola, publicado en Roma en 1562; el Libro appartenente all'Arquitectura, Roma 1552, de Antonio Labaco; De Arquitectura de Vitrubio, posiblemente la traducción de Miguel de Urrea en Alcalá de Henares en 1582, porque la de Lázaro de Velasco de 1564 no se editó hasta el año 1999 y no es probable que Arfe llegase a conocer el manuscrito ${ }^{39}$. También figuran en el inventario arfiano el Tratado de Mathematicas en que se contiene cosas de Arithmetica. Alcalá de Henares, 1573, de Juan Pérez de Moya, y Los seis primeros libros de la geometria de Euclides, seguramente la traducción sevillana de Zamorano en $1576^{40}$. Algunos de estos autores constituyen el fundamento y el punto de partida de los Libros I y IV de la Varia Commensuración que el platero estaba redactando por estos años, al mismo tiempo que labraba la custodia de la catedral, y, junto con algunos otros libros recogidos en el inventario componen un repertorio selecto de temas, idóneo para configurar la biblioteca de un artífice humanista que se autodenominaba «arquitecto y escultor de oro y plata».

Desde estas perspectivas y con un carácter fuertemente didáctico, Arfe escribe el Libro I de la Varia Commensuración dedicado a la geometría, resumiendo y sintetizando los fundamentos de Euclides a través de explicaciones sencillas, en prosa y en verso, y de dibujos com-

\footnotetext{
${ }^{37}$ A. J. Morales: «Arte y ciencia en la Sevilla del siglo xvi. Los manuscritos del cosmógrafo Rodrigo Zamorano», Actas del X Congreso del CEHA. Los clasicismos en el Arte español, Madrid, 1994, pp. $453-457$ y «El cosmógrafo Rodrigo Zamorano, traductor de Alberti al español», Annali di Architecttura, 7 (1995) 141-146

${ }^{38}$ D. García López: «De «platero» a «escultor..., p. 136. No hay que olvidar que la obra de Zamorano Cronología y repertorio de la razón de todos los tiempos, Sevilla, 1585, incorpora un retrato del autor que se ha llegado a atribuir al propio Arfe.

${ }^{39}$ De la traducción de Miguel de Urrea hay edición facsímil en Albatros, Valencia, 1978. De la de Lázaro de Velasco, la reciente de Cáceres, 1999, con estudio y transcripción de textos de F. J. Pizarro Gómez y P. Mogollón Cano.

${ }^{40}$ E. García Chico: Documentos..., p. 55 y J.L. Barrio Moya: «El platero Juan de Arfe..., pp. 8-9. «...Un libro de Biñola de Arquitectura tasado en diez y ocho riales. Un libro de Antonio la Baco de Arquitechura, tasado en diez y ocho reales. Un libro de los seis primeros que trata de la geometria de uclides, tasado en seis reales. Arimetica de Moya tasado en dos reales. Otro de Vitrubio en diez reales...». Por supuesto que Arfe contaba también con las obras de Benvenuto Cellini y Alberto Durero, este último muy utilizado en el Libro II de la Varia.
}

AEA, LXXVI, 2003, 304, pp. 371 a 388 
prensibles para los no expertos en matemáticas ${ }^{41}$. Pero para el trazado de los óvalos y de «figuras de huevo natural», como los dibujos 4 al 7 (libro I, tít. I, cap. III) no contemplados por Euclides, el platero recurre a dibujos de Serlio (libro I, folio 12v) y dirige estas formas fundamentalmente al diseño de vasos litúrgicos, siguiendo en este punto la opinión de Alberti sobre la necesidad de fabricar piezas nobles y dignas para el servicio del culto, como más adelante detallaremos (Figs. 3-4). Así pues, partiendo de Serlio y de Alberti, Arfe da las pautas para trazar formas geométricas ovoides, insistiendo en algunos diseños, como los del folio $11 \mathrm{v}$, que considera los más adecuados para facilitar la ejecución de vasos ${ }^{42}$.

El Título I del Libro IV de la Varia, que trata de los órdenes clásicos, está también basado en el Libro IV del tratado de Serlio que, por primera vez, analiza los cinco órdenes básicos incluyendo el toscano y el compuesto. Pero, en lugar de la presentación simultánea de todos los órdenes y de la explicación de sus posibles significados simbólicos, Arfe comienza su discurso con una apretada síntesis histórica de la arquitectura, desde la Antiguiedad hasta el siglo XVI, haciendo también un repaso de la historia del arte español según el concepto de «renascita vasariano» que contabiliza un tiempo en edades circulares con periodos de auge y decadencia» ${ }^{43}$. Entre los italianos destaca a Donato Bramante, Baltasar Peruzzi y Leon Baptista Alberti, y de los españoles menciona a Alonso Berruguete, Gaspar Becerra, Alonso de Covarrubias y a Diego de Siloe, además de a los plateros Antonio de Arfe, Juan Álvarez, Alonso Becerril y Juan Ruiz el Vandalino, culminando en Juan de Herrera, cuya fábrica de el Escorial entiende como el ejemplo supremo de superación de lo antiguo ${ }^{44}$. Acto seguido, igual que Serlio, Arfe nos ofrece un análisis completo y preciso de los órdenes, y los define como una articulación coherente de elementos sujetos a relaciones proporcionales (pedestal, basa, fuste, capitel, arquitrabe, etc.), a través de un reducido número de dibujos que resumen lo esencial de cada uno. Casi todos estos dibujos están tomados de los correspondientes de Serlio y algunos motivos ornamentales, como la roseta de la metopa del friso dórico o el dibujo del capitel corintio, se repiten de manera literal (Por ejemplo, las ilustraciones del Libro IV, Tít. I, f. 5, 7, 8, 13 y 17 de Arfe equivalen a las de Serlio, Libro IV, f. VII. XX-XXI, XL, LXV B, respectivamente.) (Figs. 5-6).

Entre los pocos detalles de los tres órdenes básicos que escapan a esta influencia se encuentra la voluta jónica del folio 13, dibujada con la ayuda del «cuadrado auxiliar para el control de los centros», según la solución definitiva para el trazado de espirales que se incorporó por primera vez en el año 1556 en el Vitrubio de Daniel Bárbaro con dibujos de Palladio y en 1562 en las Reglas de Vignola ${ }^{45}$. Ello demuestra que Arfe manejó también alguno de estos tratados italianos bien en las bibliotecas sevillanas bien en su librería particular, no olvidemos que el de Vignola es uno de los títulos inventariados a su muerte. También pudo aprender esta solución en el manuscrito de Hernán Ruiz, que lo reproduce en el folio 48.

Por lo que respecta al orden compuesto o romano, Arfe sigue también a Serlio. En consecuencia, los dibujos correspondientes presentan una mezcla de jónico y corintio, con la articulación del friso a base de modillones, y en el texto se menciona la posibilidad de utilizar diversos modelos de capiteles para obtener mayor efecto de riqueza. En cuanto a los «términos», «qes una manera de columnas tomadas de las Caryatides y Persicas, q(ue) primero vsaron los Griegos», considera que había que superponerlos sobre el orden compuesto y que sobre estos términos debían situarse, a su vez, los balaustres «q(ue) son otra manera de columnas que vsaron los

\footnotetext{
${ }^{41}$ A. Bonet Correa: Figuras, modelos e imágenes..., $54-55$ y 89-90.

${ }^{42}$ Véanse las figuras 10 y 11.

${ }^{43}$ Así lo califica D. García González: «De «platero» a «escultor de oro y plata»..., p. 139

${ }^{44}$ Un comentario sobre esta revisión histórica en $\mathrm{M}^{\mathrm{a}} \mathrm{J}$. Sanz Serrano: «Aspectos teóricos...», pp. 319-320.

${ }^{45}$ A. L. Ampliato Briones: «Los órdenes y las trazas», Libro de Arquitectura ..., V. II pp. 163.
} 

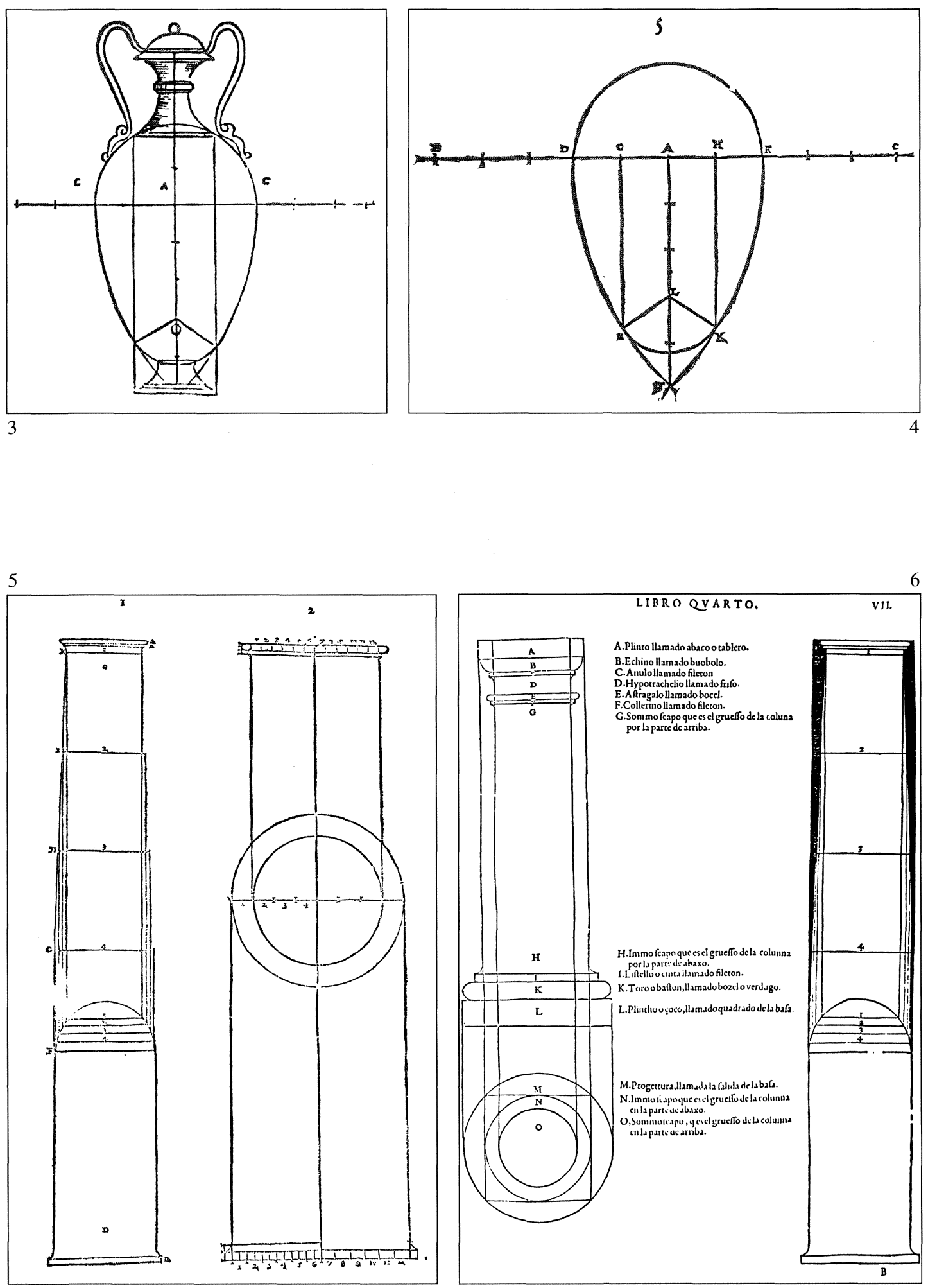

Fig. 3. Serlio. Libro I de Geometría, f. 12v.

Fig. 4. Arfe. De Varia ..., Libro I, f. 11, fig. 5.

Fig. 5. Arfe. De Varia..., Libro IV, f. Tít. I, f.5.

Fig. 6. Serlio. Libro Quarto, f. 7. 
Barbaros...». Para Serlio, en cambio, las cariátides se refieren al orden corintio y tanto los términos como los balaustres los aplica en su tratado a la traza de chimeneas (Libro IV, fs. LXIII y LXVII) o a la portada. Por lo tanto, desde el punto de vista defendido por Arfe en la Varia, la custodia de Ávila habría que valorarla como un ensayo consciente del artífice por incorporar en una arquitectura la secuencia completa de todos los órdenes, superpuestos de forma correcta, y no como una simple acumulación de elementos arquitectónicos, como parece en principio, si bien el resultado no debió satisfacerle por completo porque nunca volvió a repetirlo.

Arfe se aparta también de Serlio en su manera de interpretar los fustes de las columnas acanaladas que divide por tercios en el orden corintio y por mitades en el compuesto, revistiendo algunos de estos sectores de copiosa ornamentación vegetal o figurativa similar a la de los frisos correspondientes. Aunque la finalidad sea enriquecer la composición y, quizás, mantener en vigor parte del lenguje decorativo tradicional, el resultado entraña cierta contradicción respecto a su propia teoría y a su opiniones expresadas en las páginas de la Descripción de la traza de la custodia de Sevilla, donde muestra su admiración por la obra de El Escorial y condena «por vanas... las menudencias y resaltillos, estípites, mutilos cartelas y otras burlerías que, por verse en los papeles y estampas flamencas y francesas, siguen los inconsiderados y atrevidos artífices...». Para completar el apartado de los órdenes Arfe añade un capítulo sobre la columna ática, que identifica con la pilastra, y sobre su funcionalidad para trasdosar las columnas.

El título II del Libro IV, dedicado a las piezas de iglesia, es la aportación más original de la Varia. Según Bonet Correa, el punto de partida se relacionaría con el deseo expresado por Alberti en el capítulo XIII del Libro VII de su tratado sobre Los Diez Libros de Arquitectura, «Cómo se adorna el altar del sacrificio», donde insiste en la conveniencia de utilizar piezas nobles y dignas para el culto para que «se miren con admiración y dignidad» ${ }^{46}$. No hay que olvidar que Rodrigo Zamorano acababa de traducir el texto de Alberti al español y es seguro que el platero debió manejarlo. Pero, como el propio Arfe reconoce en el Libro IV, tít. I, f. 3, ya con anterioridad su padre y otros artífices de su generación habían comenzado a «dar forma razonable a las pieças que se hazen de plata y oro para el servicio del culto divino...». De cualquier forma, el Título II del Libro IV de Arfe supone la aplicación de los órdenes y de las proporciones a estructuras de planta central, como andas, custodias y manzanas de templete, haciendo extensivo el estudio de las proporciones a las restantes piezas litúrgicas de formato no arquitectónico.

Para el trazado de las andas se toman como punto de partida cada uno de los tres órdenes fundamentales que se aplican ahora a trazas tridimensionales de planta cuadrada y de dos cuerpos. Aunque en el capítulo V del Libro IV referido a las custodias de asiento, el artífice afirma que la plata «no admite la orden Dorica, por desnuda de ornato, y malos de poner los triglifos en los fressos», sin embargo dedica un amplio apartado a las andas dóricas (Fig. 7). Más que contradicción con su propia teoría, suponemos que la inclusión del orden dórico obedeció a la intención expresa del artífice de que su tratado sirviese a los arquitectos y tracistas en general, no sólo a los plateros, dado que los templetes y andas de madera o de piedra eran piezas habituales en la época. La iconografía de las trazas del sagrario y de la custodia del monasterio de El Escorial, diseñadas por Juan de Herrera, que se difundieron a través de las estampas de Perret grabadas en 1583-84, constituyen el máximo ejemplo a este respecto y evidencian, por otra parte, que el platero pudo tenerlas en consideración, ya que ofrecen ciertas semejanzas, excepto en las proporciones, con el dibujo arfiano ${ }^{47}$. Además, Arfe pudo ver en Sevilla un dibujo muy próximo al del sagrario escurialense en el folio 117 del Libro de Arquitectura de

\footnotetext{
${ }^{46}$ A. Bonet Correa: Figuras, modelos e imágenes..., pp. 89-90.

${ }^{47}$ Un estudio sobre la serie en E. Santiago: «Estampas de la Fábrica de San Lorenzo el Real de El Escorial», El Escorial en la Biblioteca Nacional, Madrid, 1986, pp. 230-252
} 

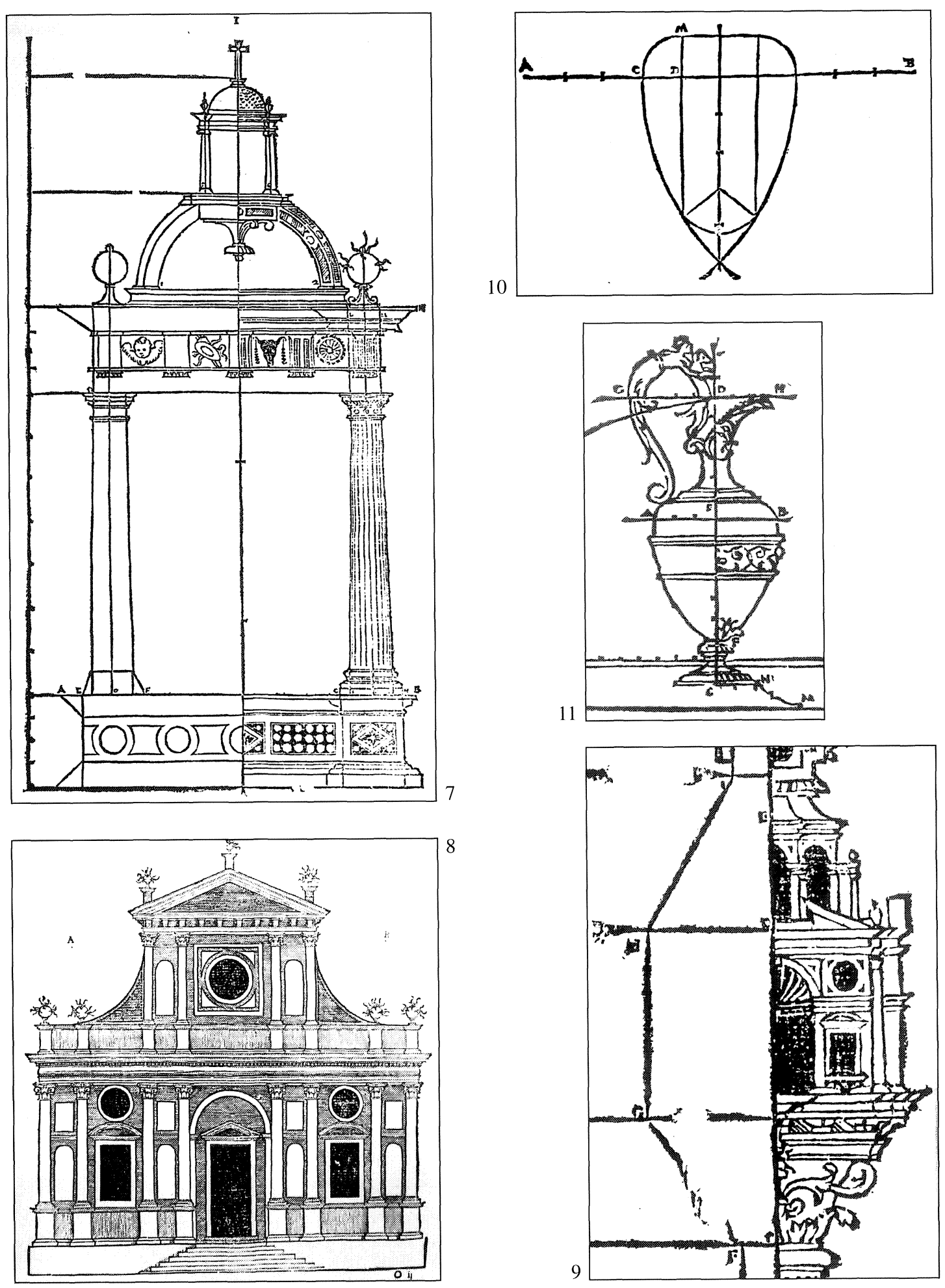

Fig. 7. Arfe: De Varia..., Libro IV, Tít. II, f. 24.

Fig. 8. Serlio. Libro Quarto, f. 56.

Fig. 9. Arfe: De Varia..., Libro IV, Tít. II, f. 32v.

Fig.10. Arfe: De Varia..., Libro I, f. 11v.

Fig. 11. Arfe. De Varia..., Libro IV, Tít. II, f. 30v. 
Hernán Ruiz. De cualquier forma, las andas vuelven a repetir literalmente el friso de Serlio e incorporan como remates de los ángulos sus características esferas llameantes o «eolípilas» — de Eolo- reproducidas en muchos dibujos del boloñés y recogidas también con cierta frecuencia por Hernán Ruiz «el Joven». Arfe pudo inspirarse en cualquiera de las estampas de frontispicios o chimeneas del Libro IV de Serlio (Fig. 8), en los dibujos de los folios 123, 123v, 138v, 139, etc del Manuscrito de Arquitectura o en la propia Giralda. Tanto para el tratadista italiano como para el arquitecto andaluz estos motivos tienen un complejo simbolismo relacionado con los cuatro elementos y una clara relación con el fuego y el aire, recogido de Vitrubio ${ }^{48}$. Es seguro que Arfe manejó el texto de Vitrubio y, posiblemente, el de Hernán Ruiz ${ }^{49}$, pero ignoramos hasta qué punto era consciente del significado simbólico de estas formas esféricas, porque la Varia no da ninguna explicación al respecto. No obstante, hay que considerar que la incorporación de las «eolípilas» en las andas dóricas obedeció al deseo del artífice de dotarlas de una funcionalidad específica, semejante a las del campanario hispalense que, como es sabido, se utilizaron como pebeteros en las luminarias hasta bien entrado el siglo XIX. El dibujo de las andas jónicas de la Varia incorpora blandones y ciriales en los remates del primer cuerpo que irían destinados a cumplir parecidas funciones de iluminación, y, en la práctica, Arfe introdujo también la «eolípilas», al menos en dos ocasiones, como coronamiento del primer cuerpo de la custodia de Valladolid y del dibujo de la Varia, Libro IV, tít. II, f 38, aunque no sabemos si como simple ornamento. Distinto parece el dibujo de las andas corintias en las que los remates simulan floreros y esculturas de bulto.

En otras piezas de iglesia, como portapaces, cruces parroquiales, cálices o cetros, Arfe aplica los órdenes a las estructuras de carácter arquitectónico - manzanas de templete y portapaces, por ejemplo- $-\mathrm{y}$, pese a su reducido tamaño, algunos diseños denotan su procedencia de portadas de Serlio. Por ejemplo, la manzana de la cruz parroquial reproducida en el folio $32 \mathrm{v}$, presenta dos cuerpos decrecientes de planta cuadrada, articulados por columnas. El inferior, culminado en frontones rectos partidos, se divide en tres calles. La central, de mayor tamaño, tiene un dintel avenerado y las laterales dinteles con frontones curvos y con círculo superior inscrito en un cuadrado (Fig. 9). La composición general puede proceder del mencionado dibujo de frontispicio de Serlio (Fig. 8). En cuanto a la aplicación por parte de Arfe de un ajustado sistema de proporciones a éstas y a otras piezas de iglesia no arquitectónicas, el posible punto de partida a nivel teórico sería Alberti, como antes dijimos, pero, en la práctica, no supuso otra cosa que codificar y dar carta de naturaleza a lo que, de manera aproximada, venían practicando en la platería española del siglo XVI muchos artífices desde mediados de siglo ${ }^{50}$.

\footnotetext{
${ }^{48}$ Según la traducción de Miguel de Urrea, el párrafo correspondiente de De Architectura de Vitrubio, Libro I, folio 15v dice así: «El viento es una ola de ayre, que corre con incierta abundancia de movimiento, el nace quando el calor demasiado topa con el humor, y el impetu y furia del calor alança la fuerça del espiritu que sopla . Y que esto sea verdad, puedse conoscer de los basos Aeolipiles, que son unos basos de arambre redondos, huecos por de dentro con un agujerito muy pequeño, y de las razones del cielo escondidas, las quales declaran la virtud de la divinidad con invenciones artificiales. Hazense pues unos basos de arambre gruessos, los quales tienen un punto, o agujerico angostissimo y muy pequeño por el qual los hinchen de agua, y puestos al fuego, antes que se calienten, no tienen espiritu ninguno, y luego que comiençan a hervir con el fuego hazen un vehemente soplo...».

${ }^{49}$ A. Jiménez Martín: «El libro de las portadas», Libro de Arquitectura ..., T. II, pp. 243 señala la presencia de las «eolípilas» o bombas relacionadas con el fuego en la «portada dórica doble», folio 123 del manuscrito, y comenta este significado simbólico en relación con los cuatro elementos de Empédocles. El texto de Vitrubio lo incorpora también Hernán Ruiz en el folio 8 del T. I del Manuscrito: «Biento es una onda corriente de ayre con yncierta moderança de mobimiento. Naçe quando el herbor e calor ofende el umor, que es el agua, y el espiritu del herbor esprime la fuerça del espiritu que sopla, yque sea esto verdad puedese ver bien en unas pelotas cóncabas de metal y puedese bien esprimentar y aclarar la beridad de la dinidad de las razones ascondidas del çielo, artifiçiosas razones de las cosas naturales, fázense estas pelotas de metal concabas y tienen un punto muy angosto por el qual se enbasa el agua, anse de poner al fuego y, antes que se escalienten nengún espíritue como comiençe a herbir, hazen en el fuego un behemente flaco o según biento...»

${ }^{50}$ J. F. Esteban Lorente: «Sistemas proporcionales en la platería aragonesa del Renacimiento y Barroco», Artigrama, ${ }^{\circ}$ $5,1988,145-165$.
} 

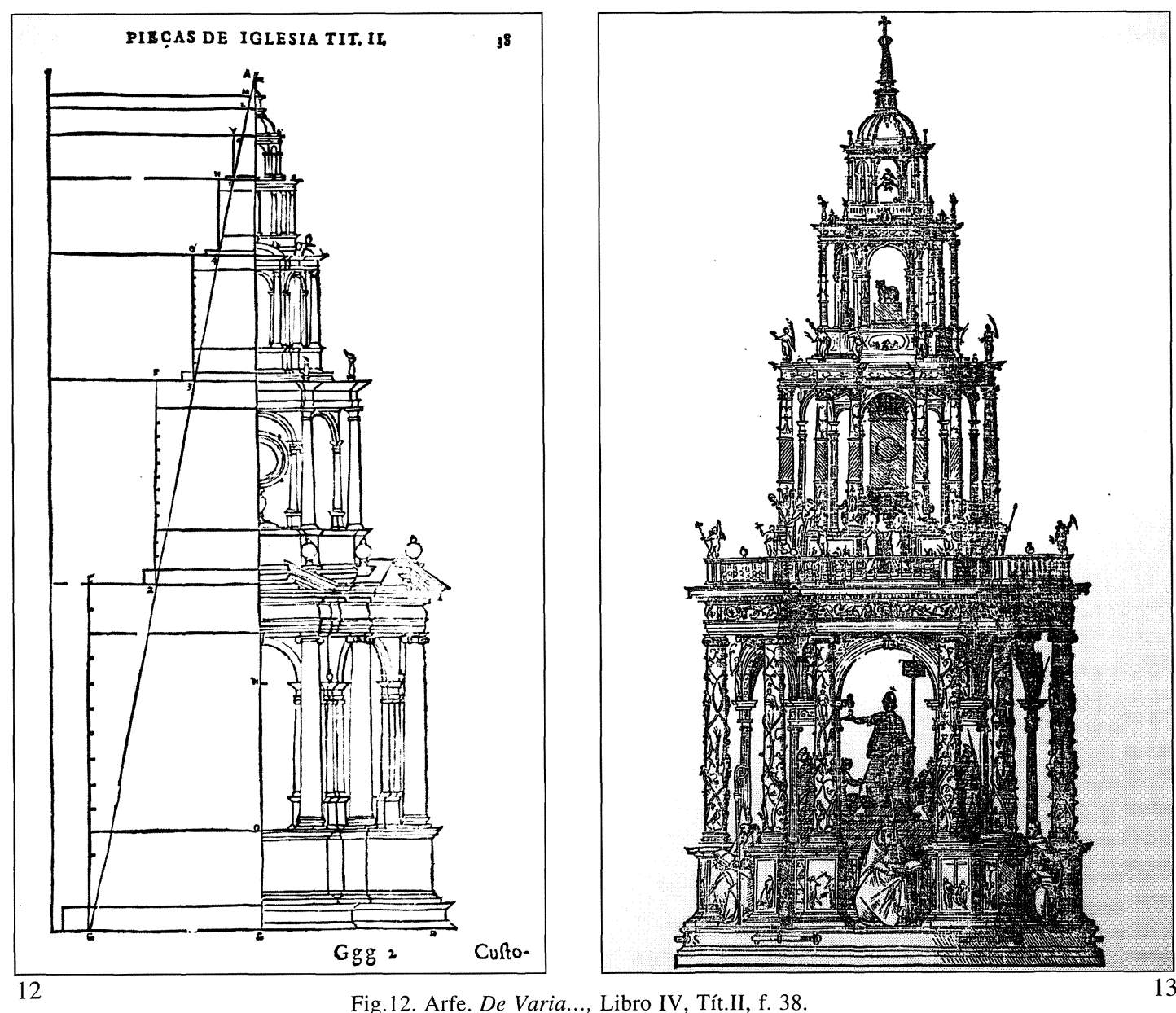

Fig.12. Arfe. De Varia..., Libro IV, Tít.II, f. 38.

Fig.13. Arfe. De Varia..., Libro IV, Tít. II, f. 38v.

De cualquier forma, algunos diseños «en forma de huevo», como el aguamanil del folio 30v, están trazados siguiendo las directrices marcadas por Serlio según la interpretación que Arfe hace en su Libro I, folio $11 \mathrm{v}$, es decir, modificando la parte superior porque como «en estos cuerpos siempre se ponen cuellos de diversos modos, conviene que no suba tanto aquella parte como sube el medio circulo...» (Figs. 10-11).

Gran interés presenta también la estructura de la custodia de asiento, ejemplificada en el Libro IV de la Varia a través de dos modelos distintos. El primero de ellos, reproducido en los folios $37 \mathrm{v}$ y 38 , con cinco cuerpos, plantas hexagonales y circulares alternantes y superposición de órdenes a partir del jónico, «como lo segui yo en la custodia de Ávila» parece, efectivamente, una reflexión sobre la estructura abulense, vista desde unos parámetros clasicistas más rigurosos y purificada ahora de sus posibles excesos formales para ajustarla a las directrices de Serlio (Fig. 12). De ahí el mantenimiento del diseño general con sus cinco cuerpos, pero la sustitución de los términos y de los balaustres por variaciones de capiteles compuestos porque, como afirma Arfe recogiendo de nuevo el comentario del boloñés sobre el orden romano, «en el querpo quarto y quinto van sucediendo con la orden composita con diversos capiteles imitando los vestigios antiguos en todo» ${ }^{51}$.

\footnotetext{
${ }^{51}$ J. de Arfe Villafañe: De Varia Commensuración..., Libro IV, tít. II, cap. V, fol. 37. Esta relación con la custodia de Ávila ya la apuntó $\mathrm{M}^{\mathrm{a}} \mathrm{J}$. Sanz Serrano: Juan de Arfe..., pp. 153-155.
} 

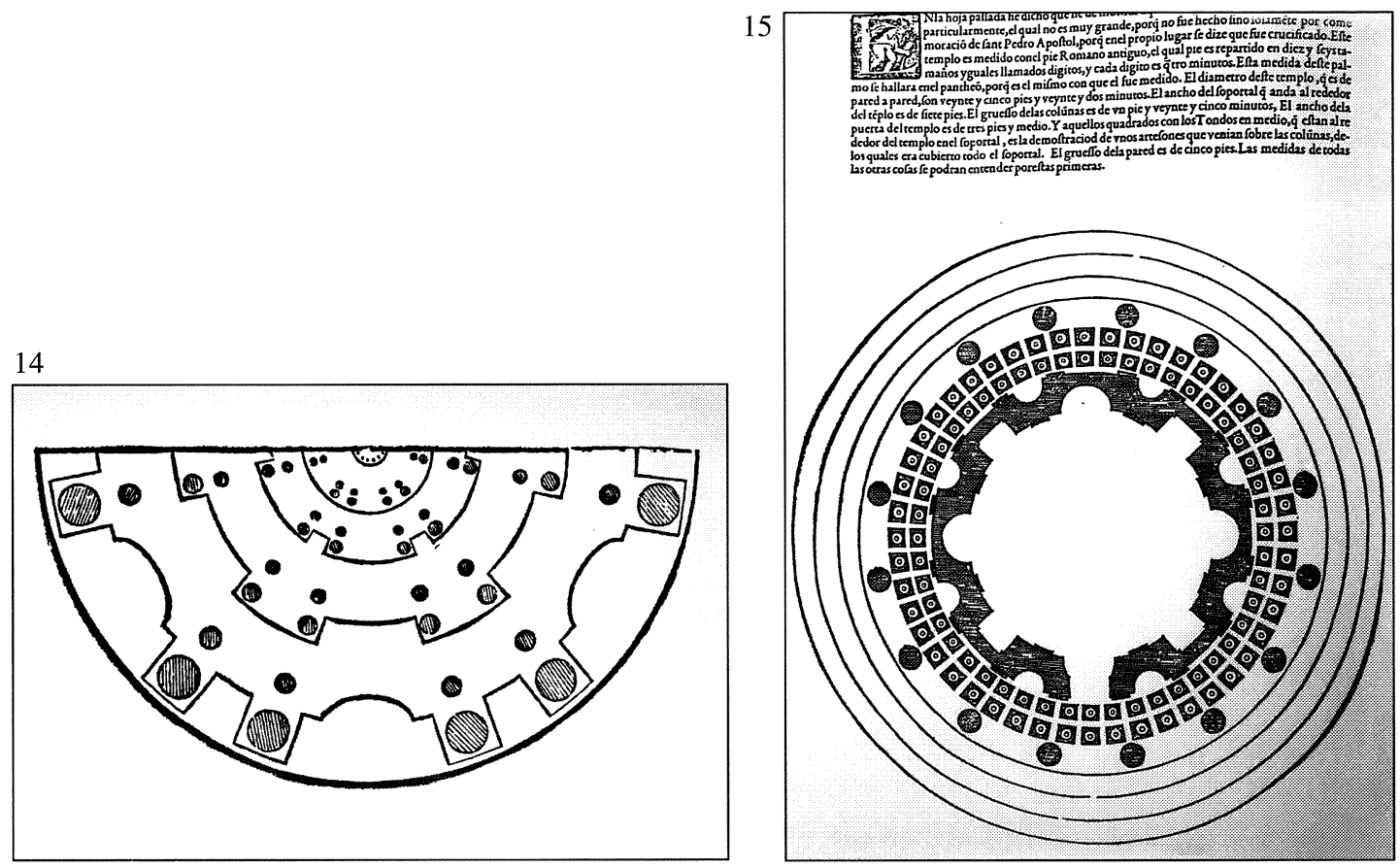

17
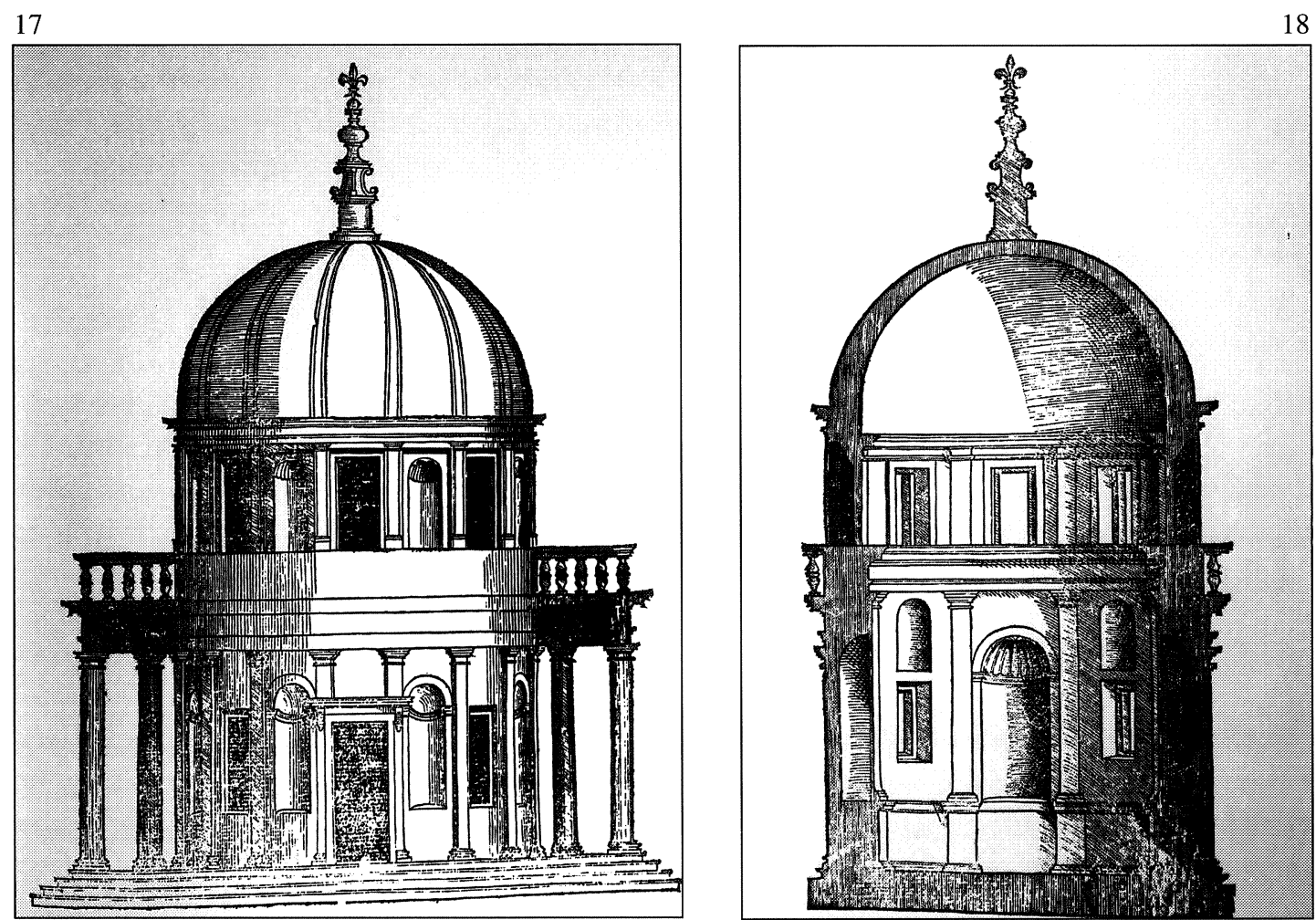

Fig.14. Arfe. De Varia..., Libro IV, f. 39

Fig. 15. Serlio. Libro Tercero, f. $23 \mathrm{v}$.

Fig. 17. Serlio. Libro Tercero, f. 24.

Fig.18. Serlio. Libro Tercero, f. $24 \mathrm{v}$. 
El segundo modelo se identifica con la custodia de la catedral de Sevilla, la obra cumbre de Juan de Arfe, y reproduce fielmente la traza de la pieza de plata, de la que se conserva también la maqueta en madera que realizó Antón de Luque en el año 1580 bajo la dirección del artífice (Fig. 13) ${ }^{52}$. Frente a la de Ávila, la custodia de Sevilla reduce a cuatro el número de cuerpos - jónico, corintio y dos superiores de orden compuesto-, ajustados a la proporción dupla sexquiáltera como él mismo defiende en teoría, y se organiza exclusivamente mediante plantas circulares (Fig. 14). Sin lugar a dudas, el punto de partida para este tipo de planta central fue la teoría de Alberti y su consideración del círculo como la figura geométrica más perfecta ${ }^{53}$, pero el resultado es absolutamente novedoso y excepcional en la platería española del quinientos y bastante raro en la arquitectura contemporánea: De hecho, en el contexto sevillano sólo tenemos noticia del monumental tabernáculo para el Sagrario que se contrató en el año 1565 con el escultor Juan Bautista Vázquez el Viejo y con el marmolista milanés Francisco de Carona conforme al diseño de Hernán Ruiz el Joven Esta obra no ha llegado a nuestros días, pero, según la documentación, se trataba de un templete circular asentado sobre unas gradas y constituido por tres cuerpos decrecientes superpuestos. El inferior se organizaba mediante columnas exentas sobre pedestales, a modo de peristilo; y en el cuerpo segundo había parejas de columnas «esteriores e interiores correspondiendo con las del cuerpo bajo» ${ }^{54}$. La descripción es un tanto vaga, pero nos permite imaginar un diseño similar al de la custodia de Sevilla. No obstante, hay que tener en cuenta que, pese a la semejanza del tabernáculo con la custodia, por su planta central y por su desarrollo vertical en cuerpos decrecientes, sin embargo fue el modelo de aquél el que serviría de inspiración a ésta y no al contrario, porque no existen precedentes de custodias turriformes con todos sus cuerpos circulares.

De cualquier manera, la custodia de Sevilla es la pieza más extraordinaria de la platería española de la segunda mitad del quinientos y la obra más personal del platero, producto, creemos, de la asimilación del pensamiento de Alberti, de la posible influencia del tabernáculo de Hernán Ruiz y de una profunda reflexión personal sobre el templete de San Pietro in Montorio visto a través de los dibujos del Libro III de Serlio - no olvidemos que Bramante es uno de los arquitectos más valorados en el Libro IV de la Varia- (Fig. 15). Arfe ya había utilizado la planta circular en el cuarto cuerpo de la custodia de Ávila, pero aquí parece recoger el diseño completo de Bramante, integrado por líneas concéntricas, y lo aplica a la totalidad de la planta y alzado de su custodia, porque, como nos aclara él mismo, «siendo redondas son mas claras y de mas capazes cuerpos, como se veran en la que hize para Sevilla» (Fig. 16) ${ }^{55}$. Por esta razón construye una arquitectura de planta central a base de los círculos concéntricos formados por las plantas decrecientes de los distintos cuerpos si bien anima su perímetro con las líneas quebradas de los plintos de los soportes externos. Cada uno de los cuatro cuerpos está compuesto por dos filas concéntricas de soportes - la exterior a manera de peristilo-, el cuerpo bajo se corona por una barandilla abalaustrada y el superior por una cúpula de media naranja, igual que en el templete romano (Fig. 17). Las columnas pareadas exteriores soportan trozos de entablamentos que siguen un ritmo alterno, doblando o no los arcos interiores. En cuanto a la fila interior de los soportes, el cuerpo bajo se articula mediante serlianas, con parejas de columnas que sujetan arcos de medio punto entre dinteles y sobre estos últimos se ajustan hornacinas con veneras. Parece que se trata de «modelar» el muro para obtener un efecto análogo al del templete bramantino en la reproducción de Serlio (Figs. 17-18). También se aproximan a los dibu-

\footnotetext{
${ }^{52}$ Sobre la custodia de Sevilla consúltese M ${ }^{\mathrm{a}}$ J.Sanz Serrano: El platero Juan de Arfe...; J. Palomero Páramo: «La platería en la catedral de Sevilla», La catedral de Sevilla, Sevilla, 1984, pp. 636-641 y J.M. Cruz Valdovinos: Cinco siglos de platería sevillana, Sevilla, 1992, p. 66-74.

${ }^{53}$ L.B. Alberti: De re aedificatoria, Madrid, 1991, con prólogo de J. Rivera, Libro VII, cap. 4 y Libro IX, cap. 5.

${ }^{54}$ A. Morales: Hernán Ruiz..., p. 57.

${ }_{55}$ J. de Arfe y Villafañe: De Varia..., Libro IV, tít. II, capV, fol. 37.
}

$A E A$, LXXVI, 2003, 304, pp. 371 a 388 

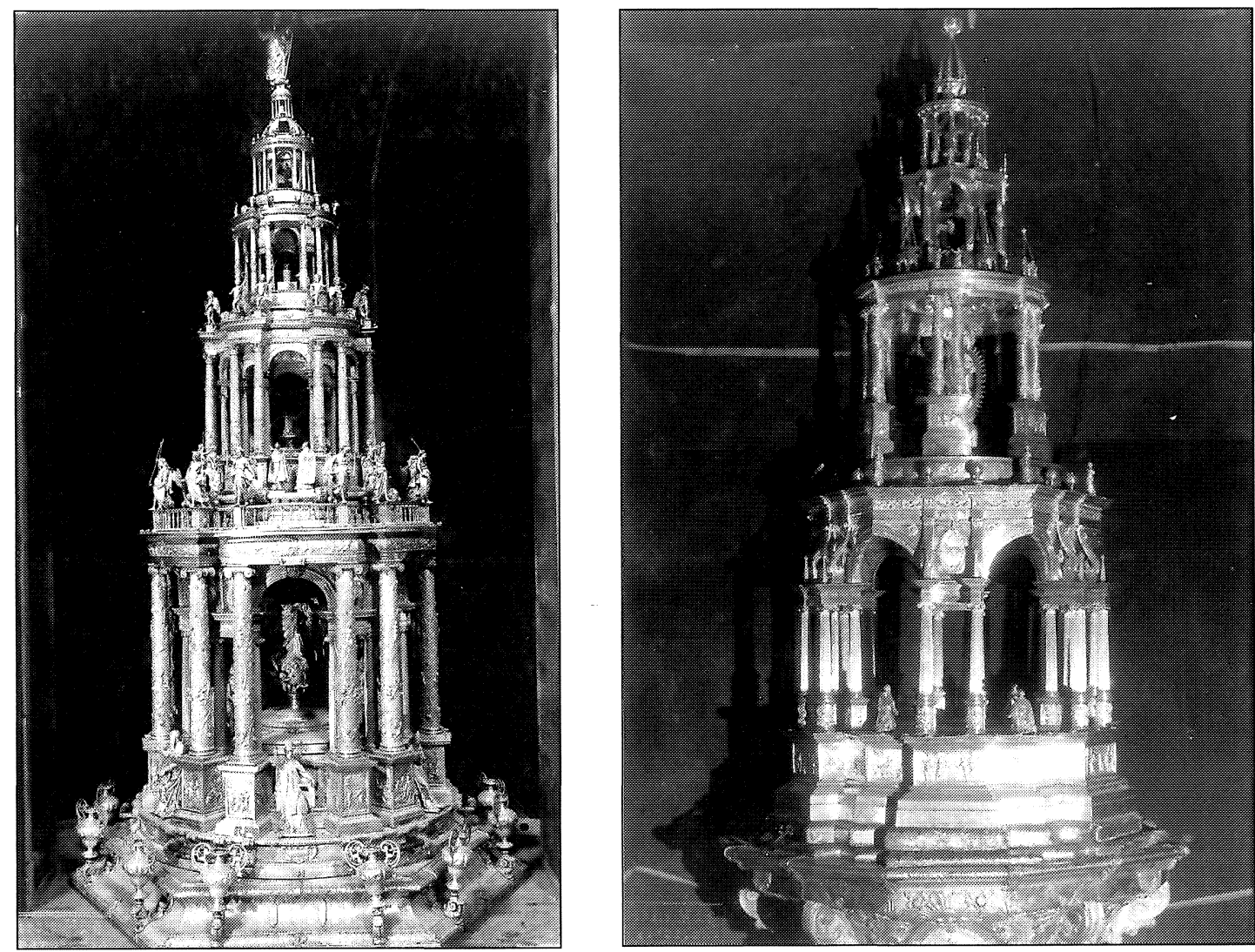

16

Fig.16. Arfe. Custodia. Catedral de Sevilla (Foto CSIC)

Fig. 19. Arfe. Custodia. Catedral de Valladolid (Foto CSIC).

jos del boloñés las serlianas que articulan los cuerpos tercero y cuarto - arcos sobre dinteles sujetos por parejas de columnas y culminados por recuadros con óculos-, semejantes a las de las portadas y puertas reproducidos en los folios IX, XXXI y XLVII del Libro IV, y los arcos con frontones rectos que articulan los intercolumnios del cuerpo segundo, si bien, en este último caso, sobre las columnas apoyan trozos de entablamento, a la manera de Diego de Siloe.

En suma, la traza de la custodia de Sevilla parece inspirada sustancialmente en Bramante a través de Serlio y, quizás también, en Hernán Ruiz «el Joven», pero su Clasicismo queda semioculto y pasa desapercibido a primera vista por quedar envuelto en un profuso lenguaje ornamental y figurativo, que le presta riqueza y opulencia. Donde mejor se perciben las líneas del diseño original de Arfe es en la maqueta de madera, que ofrece la estructura al desnudo, desprovista de ornatos y de los añadidos barrocos, salvo en lo que respecta a las proporciones que no responden ni a la duplaxesquiáltera, como sería preceptivo en una pieza de más de una vara de alto, ni tampoco a la dupla, aunque se aproxima más a esta última ${ }^{56}$.

En cuanto a las obras posteriores, la custodia de la catedral de Valladolid que Juan de Arfe contrató en el año 1588 supone una versión clasicista, revisada y simplificada de la de Ávila, reducida ahora a cuatro cuerpos y eliminados los estípites, balaustres y torrecillas angulares (Fig. 19). En cambio, las serlianas de la planta tercera cobran nuevo protagonismo y se repiten también en el cuerpo bajo, el cual se corona ahora con las «eolípilas», ya ensayadas por Arfe

\footnotetext{
${ }^{56}$ Las medidas de la maqueta son las siguientes: alto: $97 \mathrm{~cm}$, cuerpo primero: $45 \times$ 44, segundo: 24 '5x 26 , tercero: $15^{\prime 2} 2$ $\times 15$ y cuarto: $9 \times 9^{\prime} 5$.
}

AEA, LXXVI, 2003, 304, pp. 371 a 388 
en su dibujo de andas dóricas. No obstante, quizás para adaptarse a la tradición local o para plegarse a los deseos del cabildo vallisoletano, el platero vuelve a la alternancia de cuerpos hexagonales y circulares, y mantiene en aquéllos los salientes estrellados y los arcos en ángulo. Clasicista y próxima a las dos anteriores debía ser la desaparecida custodia de la catedral de Burgos, a juzgar por la descripción de los documentos ${ }^{57}$. En cambio, en la custodia del Museo de Santa Cruz de Toledo, labrada en 1592 para el convento del Carmen de Valladolid, que es la última conservada del artífice, Arfe nos ofrece un Clasicismo riguroso y desornamentado, que rebasa el lenguaje formal y la sintaxis de Serlio. Este proceso hacia la desornamentación culminaría pocos años después en la serie de relicarios para El Escorial contratados por Felipe II en $1597^{58}$. Los de traza arquitectónica de planta circular parecen una versión simplificada del sagrario del altar mayor de la iglesia, pero otras piezas en forma de pirámides o de estructuras abstractas evidencian también el impacto que causó en el artífice la contemplación directa de la fábrica del Monasterio ${ }^{59}$.

\footnotetext{
57 A. Barrón García: «Juan de Arfe en Burgos», Burgense, n 35/1, 1994, pp. 249-261.

${ }^{58}$ F. Martín: «Relicarios y piezas de altar...», pp. 32 y ss.

${ }^{59}$ La iconografía del sagrario y de la custodia de la iglesia del monasterio de El Escorial se difundió también a través de la famosa serie de estampas de Perret realizada entre 1583 y 1598 a partir de los diseños de Juan de Herrera. Un estudio sobre la serie en E. Santiago: «Estampas de la Fábrica de San Lorenzo el Real de El Escorial», El Escorial en la Biblioteca Nacional, Madrid, 1986, pp. 230-252.
}

AEA, LXXVI, 2003, 304, pp. 371 a 388 